\title{
The effect of $17 \beta$-estradiol on cholesterol content in human macrophages is influenced by the lipoprotein milieu
}

\author{
Michael P Corcoran ${ }^{1}$, Alice H Lichtenstein ${ }^{2}$, Mohsen Meydani ${ }^{3}$, Alice Dillard ${ }^{2}$, \\ Ernst J Schaefer ${ }^{1}$ and Stefania Lamon-Fava ${ }^{1}$ \\ ${ }^{1}$ Lipid Metabolism Laboratory, ${ }^{2}$ Cardiovascular Nutrition Laboratory and ${ }^{3}$ Vascular Biology Laboratory, Jean Mayer USDA Human Nutrition Research Center on Aging, \\ Tufts University, 711 Washington Street, Boston, Massachusetts 02111, USA \\ (Correspondence should be addressed to S Lamon-Fava; Email: stefania.lamon-fava @tufts.edu)
}

\begin{abstract}
Estrogen and testosterone are thought to modulate coronary heart disease (CHD) risk. To examine how these hormones affect human macrophage cholesterol transport, a key factor in atherogenesis, we obtained monocytes from healthy male and postmenopausal female donors (age 50-70 years). Cells were allowed to differentiate in autologous serum. Human monocyte-derived macrophages (HMDMs) were exposed to estrogen, testosterone, or vehicle, during differentiation. Cells were cholesterol enriched with oxidized low-density lipoprotein (oxLDL) in the presence of treatment. Cell cholesterol mass, efflux, and the expression of proteins involved in HMDM cholesterol transport were examined. Estrogen significantly reduced cholesteryl ester (CE) content in both female and male HMDMs while having no measurable effect on cholesterol efflux. Testosterone did not affect cholesterol content or efflux. Both hormones significantly but modestly affected the gene expression of several proteins involved in HMDM transport, yet these effects did not translate into significant changes in protein expression. In THP-1 macrophages, the effect of estrogen on CE content was more potent in unloaded macrophages and was estrogen receptor dependent. A trend for a reduction in nonoxLDL uptake by estrogen was observed and was also found to be dependent upon estrogen receptor activation. Our data indicate that estrogen, but not testosterone, reduces CE accumulation in HMDMs obtained from a CHD age relevant population, independent of changes in the expression of proteins important to macrophage cholesterol transport. In THP-1 cells, this effect is reduced in the presence of oxLDL, indicating that a pro-atherogenic lipoprotein milieu is an important variable in sex hormone modulation of CHD.
\end{abstract}

Journal of Molecular Endocrinology (2011) 47, 109-117

\section{Introduction}

Macrophage cholesterol transport is an important variable in the initiation and progression of atherosclerosis. Cholesterol influx of modified lipoproteins via the scavenger receptor (SR) pathway results in cholesterol enrichment and subsequent foam cell formation, an early hallmark of atheroma lesions (Kunjathoor et al. 2002). Transporters important to influx include CD36 and the macrophage SR type A (SR-A; Kunjathoor et al. 2002). Acyl coenzyme A:cholesterol acyltransferase 1 (ACAT1) esterifies free cholesterol for storage in lipid droplets, while cholesteryl ester hydrolase (CEH) de-esterifies this cholesterol, presumably leading to cholesterol efflux (Buhman $e t$ al. 2001). Proteins important to cholesterol efflux include ABCA1, ABCG1, and apolipoprotein E (apoE; Cullen et al. 1998, Wang et al. 2007, Out et al. 2008). The SR-B1 may also play a role in cholesterol accumulation as it is a bidirectional cholesterol transporter, the function of which, however, is complicated and poorly understood, with evidence supporting roles for efflux, efflux inhibition, and influx (Chen et al. 2000, Langer et al. 2002, Yancey et al. 2003, Wang et al. 2007).

The steroid hormones $17 \beta$-estradiol $\left(\mathrm{E}_{2}\right)$ and testosterone are thought to play a role in modulating atherogenesis. $\mathrm{E}_{2}$ and testosterone treatments have been shown to alter cholesterol metabolism in human monocytederived macrophage cells (HMDMs) obtained mainly from younger men and premenopausal women (Tomita et al. 1996, McCrohon et al. 1999, 2000, Napolitano et al. 2001, $\mathrm{Ng}$ et al. 2003). $\mathrm{E}_{2}$ has been shown to reduce $\mathrm{CE}$ content in female, but not in male, HMDMs (McCrohon et al. 1999), an effect possibly caused by reduced cholesterol esterification and uptake of modified lipoproteins (Tomita et al. 1996, Sulistiyani \& St Clair 1997, McCrohon et al. 1999, 2000, Napolitano et al. 2001). Enhanced cholesterol efflux in both male and female HMDMs by $\mathrm{E}_{2}$ has also been observed, but at superphysiological concentrations (Napolitano et al. 2001). Conversely, dihydrotestosterone, the more potent, nonaromatizable form of testosterone, has been shown to increase $\mathrm{CE}$ content in male but not in female-derived HMDMs (McCrohon et al. 1999, 2000, Ng et al. 2003).

DOI: 10.1530/JME-10-0158 Online version via http://www.endocrinology-journals.org 
These studies have predominantly utilized HMDMs derived from younger male and premenopausal female donors. It is not known how HMDMs obtained from older individuals will respond to physiological concentrations of $\mathrm{E}_{2}$ or testosterone. Because the prevalence and severity of atherosclerosis increases with age (Lloyd-Jones et al. 2010), we aimed to investigate the effect of $\mathrm{E}_{2}$ and testosterone on cholesterol accumulation in HMDMs obtained from older male and postmenopausal female donors. Additionally, we studied how oxidized lipoproteins modulate the effects of $\mathrm{E}_{2}$ and testosterone on human macrophage cholesterol accumulation.

\section{Materials and methods}

\section{Materials}

Estrogen, testosterone, DNaseI, BSA, apoA-I, formaldehyde, malondialdehyde, acrylamide, phorbol 12-myristate 13-acetate (PMA), and protease inhibitor cocktail were purchased from Sigma. ICI 182780 was purchased from Tocris Biosciences (Ellsville, MO, USA). THP-1 cells were obtained from the American Type Culture Collection (Manassas, VA, USA). Charcoal/dextran-treated fetal bovine serum (FBS) was purchased from Hyclone (Logan, UT, USA). FicollPaque was obtained from GE Healthcare (Piscataway, NJ, USA). Amplex Red Cholesterol Assay Kit was purchased from Molecular Probes (Eugene, OR, USA). RNeasy Mini Kit was purchased from Qiagen. Phenol-free RPMI1640 medium and Superscript III Reverse Transcriptase Kit were obtained from Invitrogen. Power SYBR Green Master Mix was purchased from Applied Biosystems (Carlsbad, CA, USA). Bicinchoninic Acid Protein Assay Kit was obtained from Pierce (Rockford, IL, USA). DiI-low-density lipoprotein (LDL) was purchased from Biomedical Technologies (Stoughton, MA, USA). 3[H]-Cholesterol was obtained from Perkin-Elmer (Waltham, MA, USA). CD36, LDL receptor (LDLR), and ACAT1 antibodies were purchased from Cayman Chemical Co. (Ann Arbor, MI, USA). The remaining antibodies were purchased from Novus Biologicals (Littleton, CO, USA). ECL detection assay Kit was obtained from Amersham Biosciences.

\section{Subjects}

Healthy normolipidemic male $(n=10)$ and postmenopausal female $(n=10)$ volunteers between 50 and 70 years of age were recruited for this study. Subjects were included if they had no history of coronary heart disease (CHD), cancer, diabetes, or renal, liver, or thyroid diseases. Inclusion criteria were LDL cholesterol (LDL-C) $\quad<160 \mathrm{mg} / \mathrm{dl}$, high-density lipoprotein cholesterol (HDL-C) $>40 \mathrm{mg} / \mathrm{dl}$, triglycerides (TG)
Table 1 Characteristics and fasting metabolic and lipid profiles of study volunteers. Values are expressed as mean (+s.D.)

\begin{tabular}{|c|c|c|c|}
\hline & $\begin{array}{l}\text { Women } \\
(n=10)\end{array}$ & $\begin{array}{l}\text { Men } \\
(n=10)\end{array}$ & $P$ value \\
\hline Age (years) & $58.9(4 \cdot 4)$ & $60 \cdot 8(5 \cdot 9)$ & 0.4236 \\
\hline BMI $\left(\mathrm{kg} / \mathrm{m}^{2}\right)$ & $27 \cdot 6(6 \cdot 2)$ & $26.0(2.9)$ & 0.4808 \\
\hline \multicolumn{4}{|l|}{ Lipids } \\
\hline TC (mg/dl) & $205 \cdot 5(30 \cdot 5)$ & $177 \cdot 8(33 \cdot 6)$ & 0.0698 \\
\hline LDL-C (mg/dl) & $111.1(32 \cdot 5)$ & $87 \cdot 24(35 \cdot 8)$ & 0.1366 \\
\hline HDL-C (mg/dl) & $66.0(15 \cdot 7)$ & $46 \cdot 1(15 \cdot 5)$ & $0.0107^{*}$ \\
\hline $\mathrm{TG}(\mathrm{mg} / \mathrm{dl})$ & $78 \cdot 2(27 \cdot 8)$ & $99 \cdot 3(45 \cdot 8)$ & 0.2292 \\
\hline VLDL (mg/dl) & $14 \cdot 3(6 \cdot 8)$ & $10 \cdot 4(5 \cdot 8)$ & $0 \cdot 2381$ \\
\hline Glucose (mg/dl) & $90 \cdot 9(6 \cdot 7)$ & $91(8 \cdot 0)$ & 0.9762 \\
\hline $\mathrm{ER} \alpha \mathrm{IVS} 1$ & $\begin{array}{l}\mathrm{T} / \mathrm{C}=5 \\
\mathrm{~T} / \mathrm{T}=5\end{array}$ & $\begin{array}{l}\mathrm{T} / \mathrm{C}=8, \\
\mathrm{~T} / \mathrm{T}=2\end{array}$ & 0.3498 \\
\hline
\end{tabular}

${ }^{*} P$ value $<0.05$ for gender difference. TC, total cholesterol; LDL-C, lowdensity lipoprotein cholesterol; HDL-C, high-density lipoprotein cholesterol; TG, triglycerides; VLDL, very low-density lipoprotein.

$<150 \mathrm{mg} / \mathrm{dl}$, and glucose $<100 \mathrm{mg} / \mathrm{dl}$. Subjects who smoked or had hypertension were excluded from the study. Volunteers were also not taking any medications to control blood lipid or glucose levels. Women were considered postmenopausal if irregular menstrual periods exceeded 1 year. Most women $(n=8)$ in this study had been postmenopausal for $>5$ years. None of the women were on hormone replacement therapy. The study was approved by the Institutional Review Board of Tufts Medical Center, and all subjects provided informed consent. Characteristics of the subjects are shown in Table 1.

\section{Lipid measurements, and LDL isolation and oxidation}

Plasma lipid measurements including total cholesterol (TC), TG, LDL-C, and HDL-C were determined by enzymatic assays (Roche diagnostics). LDL was isolated from pooled donor plasma by rapid single-step ultracentrifugation using a Beckman NVT90 rotor (Beckman Coulter, Miami, FL, USA) as described previously (Vieira et al. 1996). LDL was oxidized at $37^{\circ} \mathrm{C}$ by the addition of $100 \mu \mathrm{M} \mathrm{CuSO}_{4} / 100 \mu$ g protein. Oxidation extent was monitored by absorbance increases at $234 \mathrm{~nm}$. When absorbance began to increase exponentially $(\approx 1.5 \mathrm{~h})$, LDL was placed on ice and immediately desalted to stop further oxidation. This typically produced a thiobarbituric acid-reactive substance (TBARS) value of between 6 and $8 \mathrm{nM}$ malondialdehyde/ $\mu \mathrm{g}$ protein, which is considered mildly oxidized LDL (oxLDL; Weidtmann et al. 1995), a form likely present in vivo (Yla-Herttuala et al. 1989). TBARS measurements were performed as described previously (Cathcart et al. 1991). oxLDL was stored at $-80^{\circ} \mathrm{C}$ in the dark for up to 2 months, as TBARS values and $234 \mathrm{~nm}$ readings were found to remain stable for this duration. Protein aggregation of 
the LDL particles was also found to be minimal for this period of time. The same batch of oxLDL was used for all experiments.

\section{Isolation and culture of HMDMs}

Blood was drawn for the isolation of monocytes, plasma (for HDL/LDL isolation), and serum following a $12 \mathrm{~h}$ fast. Buffy coats were obtained by layering blood cells diluted 1:2 with phenol-free RPMI1640 over Ficoll-Paque and centrifuged $(37 \mathrm{~min}, 394000 \mathrm{~g}$ at room temperature). White blood cells were collected and washed twice in RPMI, then plated in serum-free RPMI. After 3-4 h of incubation, non-adherent cells were washed off, and the remaining monocytes were cultured in RPMI containing 10\% autologous serum. Cells were allowed to differentiate for 10 days in the presence of vehicle $(0 \cdot 1 \%$ ethanol $)$, physiological concentrations of $\mathrm{E}_{2}$ or testosterone (2 and $10 \mathrm{nM}$ respectively), or superphysiological concentrations of $\mathrm{E}_{2}$ or testosterone (20 and $100 \mathrm{nM}$ respectively).

HMDMs were treated with $50 \mu \mathrm{g} / \mathrm{ml}$ oxLDL from days 10 to 12 in the presence of $10 \%$ autologous serum and hormone treatment. Cells were then harvested for protein, RNA, or cholesterol mass measurement. Cells were collected in lysis buffer $\left(0 \cdot 1 \mathrm{M} \mathrm{KH}_{2} \mathrm{PO}_{4}, 0 \cdot 05 \mathrm{M}\right.$ $\mathrm{NaCl}, 5 \mathrm{mM}$ cholic acid, and $0 \cdot 1 \%$ Triton $\mathrm{X}-100)$, and cell protein was quantified using the bicinchoninic acid method with BSA as a standard.

\section{Cholesterol efflux}

For cholesterol efflux, cells were treated with $2 \cdot 5 \mu \mathrm{Ci} / \mathrm{ml}^{3}[\mathrm{H}]$-cholesterol in addition to $50 \mu \mathrm{g} / \mathrm{ml}$ oxLDL during days $10-12$. After oxLDL $/{ }^{3}[\mathrm{H}]$-cholesterol exposure, cells were equilibrated in RPMI supplemented with $2 \mathrm{mg} / \mathrm{ml}$ fatty acid-free BSA for 6-8 $\mathrm{h}$, then incubated with $25 \mu \mathrm{g} / \mathrm{ml} \mathrm{HDL}+10 \mu \mathrm{g} / \mathrm{ml}$ apoA-1 + treatments for $24 \mathrm{~h}$ in serum-free medium. Exposure of HMDM to vehicle, $\mathrm{E}_{2}$, or testosterone was constant throughout these experiments. HDL used in the cholesterol efflux assay was isolated from pooled donor plasma by sequential ultracentrifugation as described previously (Havel et al. 1955). Fraction of cholesterol efflux was calculated by dividing the medium disintegrations per minute (DPM) counts by the total (medium + cell) DPM counts. These values were then adjusted for cell protein concentration.

\section{THP-1 cells}

THP-1 monocytic leukemia cells were differentiated with $100 \mathrm{ng} / \mathrm{ml}$ PMA in phenol-free RPMI medium + $10 \% \mathrm{charcoal} /$ dextrin-treated FBS for $72 \mathrm{~h}$. Cells were then washed twice in PBS and treated for $48 \mathrm{~h}$ with vehicle, $\mathrm{E}_{2} 20 \mathrm{nM}$, vehicle + ICI 182780 (an ER antagonist) $200 \mathrm{nM}$, or $\mathrm{E}_{2} 20 \mathrm{nM}+\mathrm{ICI} 182780$ $200 \mathrm{nM}$ in $10 \%$ postmenopausal female serum (PFS). Cells were then cultured with treatments in the following conditions for $48 \mathrm{~h}$ : PFS, PFS + oxLDL, and for cholesterol efflux measurement: $\mathrm{PFS}+{ }^{3}[\mathrm{H}]$-cholesterol or PFS + oxLDL $+{ }^{3}[\mathrm{H}]$-cholesterol.

\section{Measurement of cellular cholesterol content}

Cellular cholesterol content was measured fluorometrically using the Amplex Red Cholesterol Assay Kit as described by the manufacturer. Cell monolayers were washed twice and then lysed in $1 \times$ reaction buffer supplemented with $10 \mathrm{U} / \mathrm{ml}$ DNaseI. Because this lysate was also used for protein expression analysis, lysates were also supplemented with a protease inhibitor cocktail. Plates were rocked at $4{ }^{\circ} \mathrm{C}$ for $15 \mathrm{~min}$, and cells were scraped into $1.5 \mathrm{ml}$ centrifuge tubes and incubated on ice for $1 \mathrm{~h}$. An aliquot of this lysate was used for cell cholesterol mass measurement, while the remaining lysate was used for protein analysis. The aliquot for cholesterol measurement was vortexed for $30 \mathrm{~min}$ at room temperature to ensure complete homogenization of the cells. Samples were heated at $60{ }^{\circ} \mathrm{C}$ for $30 \mathrm{~min}$ to inactivate enzymes that could compete with the assay. Because this assay included cholesterol esterase, both TC and CE could be quantified. Cholesterol content was adjusted for cell protein quantity.

\section{Real-time PCR}

Total cellular RNA was isolated using the RNeasy Mini Kit according to the manufacturer's instructions. RNA was reverse transcribed using a Superscript III Reverse Transcription Kit and amplified on an Applied Biosystems 7300 real-time PCR using specific primers validated for efficiency and specificity by standard curve dilution and melting point analysis. Real-time PCR using power SYBR Green Master Mix was carried out for 40 cycles of $95^{\circ} \mathrm{C}(15 \mathrm{~s})+60{ }^{\circ} \mathrm{C}(1 \mathrm{~min})$. Changes in gene expression were assessed by $\Delta \Delta C_{\mathrm{t}}$ analysis with $\beta$-actin as the control/housekeeping gene, as the expression of this gene was unchanged with treatment (data not shown). Changes were expressed as percent of control (vehicle).

\section{Western immunoblot assay}

For HMDM, $20 \mu \mathrm{g}$ of total cell protein were separated on a $10 \%$ acrylamide gel overnight and transferred onto a nitrocellulose membrane. After blocking the membranes with $5 \%$ non-fat dry milk in TBS- $0.5 \%$ Tween 20 (blocking buffer) for 1-2 h, the membranes were incubated with primary antibody in blocking buffer overnight at $4^{\circ} \mathrm{C}$. Following washing, the 

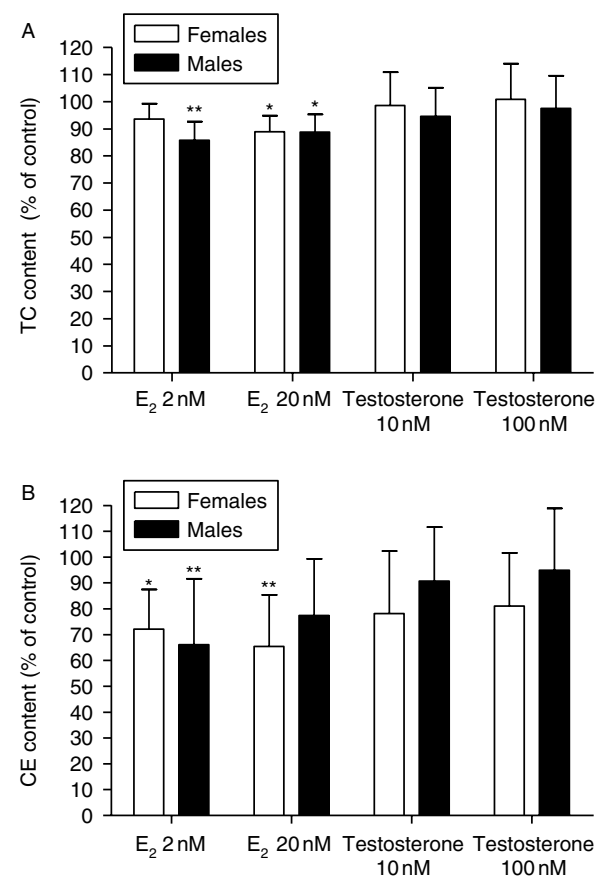

Figure 1 Effect of $17 \beta$-estradiol $\left(E_{2}\right)$ or testosterone on HMDM cholesterol content. Macrophage cells were cultured for 10 days in autologous serum along with control (ethanol), $E_{2} 2 \mathrm{nM}, \mathrm{E}_{2} 20 \mathrm{nM}$, testosterone $10 \mathrm{nM}$, or testosterone $100 \mathrm{nM}$, and then treated with oxLDL (with hormones). (A) Effect of $\mathrm{E}_{2}$ or testosterone treatment on HMDM total cholesterol (TC) content. (B) Effect of $E_{2}$ or testosterone treatment on HMDM cholesteryl ester (CE) content. Data are shown as percent of control. ${ }^{*} P<0.05,{ }^{*} P<0.01$.

membranes were incubated with secondary antibody in blocking buffer for $1 \mathrm{~h}$ at room temperature. Bands were visualized by Amersham ECL detection assay. Changes in protein expression were assessed by band optical density analysis with $\beta$-actin as the control. Changes were expressed as percent of control (vehicle).

\section{Dil-LDL uptake}

THP- 1 cells were treated with $\mathrm{E}_{2} 20 \mathrm{nM}+5 \mu \mathrm{g} / \mathrm{ml}$ DiILDL in RPMI medium containing $10 \%$ PFS for $48 \mathrm{~h}$ following differentiation with PMA. Cells were then washed several times with PBS containing $3 \mathrm{mg} / \mathrm{ml}$ fatty acid-free BSA, trypsinized $(0 \cdot 25 \%)$, and fixed with $4 \%$ formaldehyde prior to FACSCalibur analysis. Cells (10 000) were counted for fluorescence with an emission spectra set at $571 \mathrm{~nm}$ and an excitation spectra set at $554 \mathrm{~nm}$.

\section{Statistical analysis}

Statistical analyses were performed using SAS Software (v9.1, Cary, NC, USA) while graphs were created using GraphPad Prism Software (v4, La Jolla, CA, USA). Results are expressed as mean percent of control
(+ S.D.), except where noted. Means and S.D. are representative of the treatment response in macrophage cultures obtained from ten females or ten males. For THP-1 experiments, results are from three to four independent experiments where each treatment was performed in triplicate. Statistical differences were determined by two-way ANOVA for both treatment effect and sex effect using Tukey's Student Range test or by one-way ANOVA for treatment effect alone where appropriate. Significance was considered at $P<0 \cdot 05$.

\section{Results}

Table 1 describes the characteristics of participating subjects. Women had significantly higher plasma HDL-C levels than men. Plasma levels of HDL-C, LDLC, and TG did not significantly correlate with HMDM cholesterol content in control cells nor did these levels influence the treatment effect (data not shown).

$\mathrm{E}_{2} 2 \mathrm{nM}$ significantly reduced TC content in males only, while this reduction was significant in both genders at $\mathrm{E}_{2} 20 \mathrm{nM}$ (Fig. 1A). Conversely, $\mathrm{E}_{2}$ significantly reduced $\mathrm{CE}$ content in women at both concentrations. In men, the reduction in CE was significant at the $2 \mathrm{nM}$ concentration, with a nonsignificant trend $(P=0.054)$ at the $20 \mathrm{nM}$ concentration (Fig. 1B). No dose-dependent effect was observed. In contrast, testosterone treatment had no significant effect on TC or CE content in male or female donors (Fig. 1A and B). Free cholesterol levels did not change with either hormone treatment (data not shown). Neither hormone had any significant effect on HMDM cholesterol efflux (Fig. 2).

The effect of $\mathrm{E}_{2}$ or testosterone treatment on the expression of genes important for cholesterol transport was also studied. $\mathrm{E}_{2}$ induced modest reductions

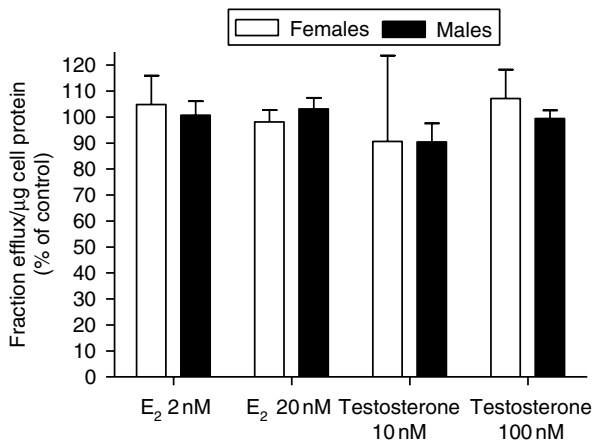

Figure 2 Effect of $E_{2}$ or testosterone on HMDM cholesterol efflux. HMDMs were exposed to hormones + oxLDL (described in Fig. 1) along with ${ }^{3} \mathrm{H}$-cholesterol. Following this, cells were exposed to HDL-C, apoA-1, and hormone treatment for $24 \mathrm{~h}$, and then fraction of cholesterol efflux $\left({ }^{3} \mathrm{H}\right.$ medium counts $/{ }^{3} \mathrm{H}$ medium $+{ }^{3} \mathrm{H}$ cell counts) was measured. 

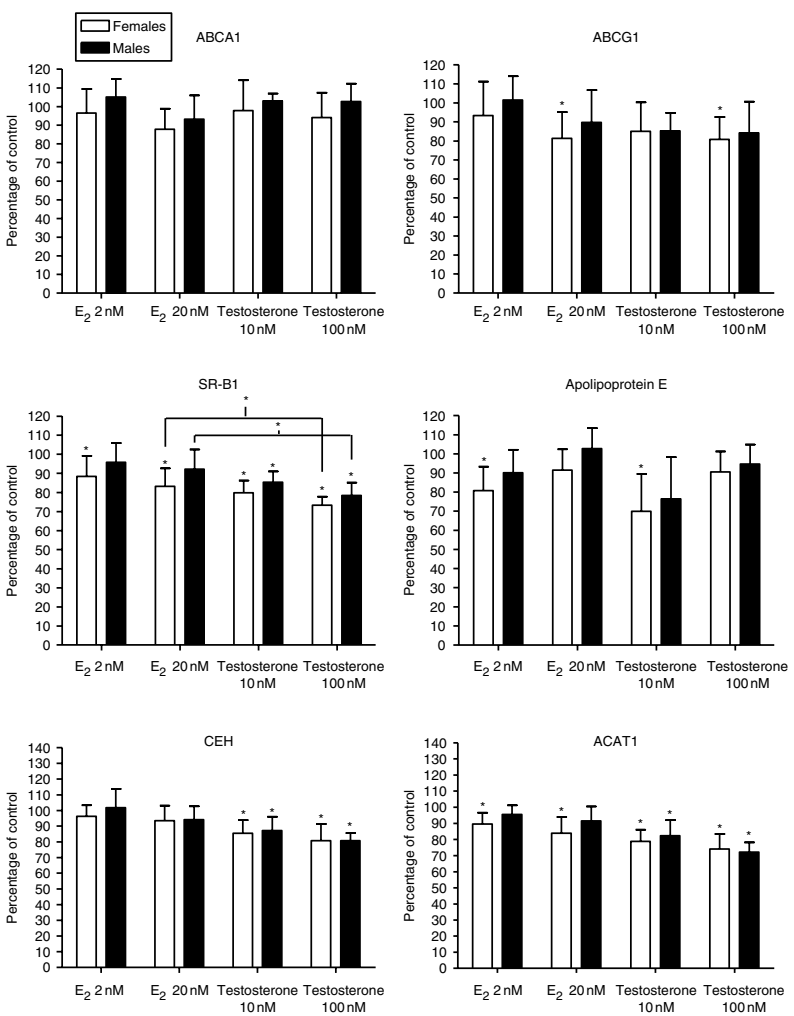

Figure 3 Effect of $E_{2}$ or testosterone on the expression of select genes involved in HMDM macrophage cholesterol transport. Following oxLDL treatment of HMDMs (described in Fig. 1), RNA was isolated and reverse transcribed, and the expression of genes involved in cholesterol efflux was measured by real-time PCR. Data are expressed as percent of control. ${ }^{\star} P<0.05$.

(10-20\%) in ABCG1, SR-B1, apoE, and ACAT1 gene expression in female but not in male HMDMs (Fig. 3), yet these effects were not observed at the protein level (Fig. 4). Testosterone reduced the gene expression of $A B C G 1$, SR-B1, apoE, ACAT1, and CEH (Fig. 3) by $10-30 \%$ but did not elicit any measurable change at the protein level (Fig. 4). No effect of $\mathrm{E}_{2}$ or testosterone was observed on the gene or protein expression of ABCA1, CD36, or MSR (data not shown).

To understand how $\mathrm{E}_{2}$ reduced cellular $\mathrm{CE}$ content in the absence of an increase in cholesterol efflux or any significant changes in the major proteins involved in cholesterol transport, we used THP-1 cells as a model. $\mathrm{E}_{2}$ treatment significantly reduced $\mathrm{CE}$ content in cells not exposed to oxLDL (Fig. 5B). This effect was abrogated by ICI 182780 treatment (Fig. 5B). After oxLDL exposure, the effect of $\mathrm{E}_{2}$ on $\mathrm{CE}$ content was smaller than that observed prior to oxLDL exposure $(-20$ vs $-40 \%$ respectively) and did not reach statistical significance despite a clear trend (Fig. 5D). There was no significant difference in TC (Fig. 5A and C) or free cholesterol (data not shown) with $\mathrm{E}_{2}$ treatment. However, we did observe a significant increase in TC and CE content by ICI treatment in THP-1 cells exposed to oxLDL (Fig. 5C and D). Reductions in THP-1 gene expression (ABCG1, SR-B1, apoE, and ACAT1) by $\mathrm{E}_{2}$ were also similar to those in the HMDMs, and there was no change in cholesterol efflux by $\mathrm{E}_{2}$ (Fig. 6A).

THP-1 cells exposed to $\mathrm{E}_{2} 20 \mathrm{nM}$ and treated with non-oxidized DiI-LDL exhibited a non-significant trend toward a reduced LDL uptake, compared with control cells, that was ablated by ICI 182780 treatment (Fig. 6B). There were no measurable differences in the protein expression of CD36, MSR, and LDLR (data not shown).

\section{Discussion}

In this study, we found that $\mathrm{E}_{2}$, but not testosterone, reduces $\mathrm{CE}$ content without altering cholesterol efflux in macrophage cells obtained from 50- to 70-year-old men and postmenopausal women. This effect was not dependent upon changes in the expression of proteins important to cholesterol transport. In the human macrophage cell line THP-1, the $E_{2}$-associated reduction in $\mathrm{CE}$ was dependent upon $\mathrm{ER}$ activation. More importantly, the reduction in CE content was more pronounced in cells not exposed to oxLDL indicating that a pro-atherogenic lipoprotein milieu is an influential factor in estrogen modulation of CHD.

The reduction in macrophage $\mathrm{CE}$ content by $\mathrm{E}_{2}$ should supposedly lead to the inhibition of foam cell formation. By mitigating foam cell formation, $\mathrm{E}_{2}$ may inhibit the progression of CHD. A reduction in $\mathrm{CE}$ content has also been reported previously in HMDM from younger donors (McCrohon et al. 1999), with $\mathrm{E}_{2}$ reducing $\mathrm{CE}$ content in premenopausal female HMDM donors, but not in male donors. We did not observe any sex-specific effects in our study, possibly due to the use

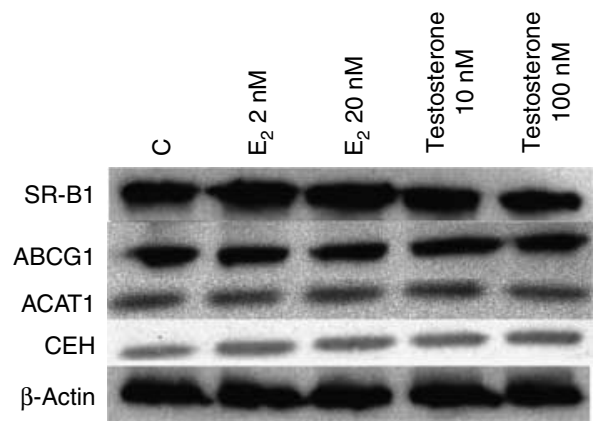

Figure 4 Effect of $E_{2}$ or testosterone treatment on the expression of select proteins involved in HMDM macrophage cholesterol transport. Following oxLDL treatment (described in Fig. 1), cell protein was collected, and the quantity of proteins involved in HMDM cholesterol transport that exhibited hormone-induced changed in gene expression was measured by western blotting. Blot shown is a representative. 

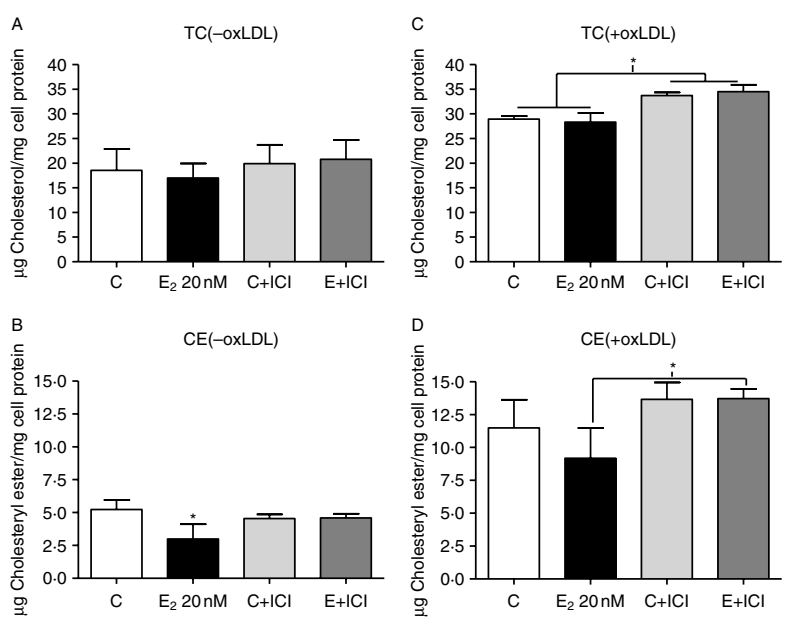

Figure 5 Effect of $E_{2}$ treatment on THP-1 macrophage cholesterol content in cells with or without oxLDL exposure. THP-1 monocytes were differentiated for 3 days and then exposed to vehicle (C), $E_{2} 20 \mathrm{nM}, \mathrm{C}+\mathrm{ICl} 182780200 \mathrm{nM}$, or $\mathrm{E}_{2}+\mathrm{ICl}$ 182780 for 2 days. TC, free cholesterol, and CE content were measured in one group and another group was treated with hormones + oxLDL for additional $48 \mathrm{~h}$, followed by cholesterol measurement. Results are expressed as mean + s.D. from three to four independent experiments, where each treatment was performed in triplicate. ${ }^{*} P<0 \cdot 05$.

of autologous serum and oxLDL (as opposed to acetylated LDL, which acutely increases HMDM CE content, yet is not present in vivo (Brown \& Goldstein 1983)). It is, however, possible that the sex-specific effect of $\mathrm{E}_{2}$ on macrophage $\mathrm{CE}$ content may be lost with age. This needs to be further investigated by direct comparison with younger donors under similar conditions. The effect of $E_{2}$ on cholesterol efflux may also be lost with age, as previous work indicated that $\mathrm{E}_{2}$ may enhance cholesterol removal from HMDM at least in male donors (Napolitano et al. 2001). In this report, however, very high concentrations of $\mathrm{E}_{2}(1.5 \mu \mathrm{M})$ were used, HMDM were exposed to acetylated LDL, and the differences between control and $\mathrm{E}_{2}$-treated HMDMs had dissipated by $24 \mathrm{~h}$ (Napolitano et al. 2001). Another report showed that THP-1 cells treated with HDL isolated from older individuals exhibited reduced efflux capacity compared with cells treated with HDL isolated from younger donors (Berrougui et al. 2007). This effect was linked with reduced ABCA1-mediated efflux (Berrougui et al. 2007), possibly indicating a reduced prevalence of lipid-poor apoA-I and nascent HDL particles in older individuals (Wang et al. 2007). How age-related HDL particle distribution influences the ability of $\mathrm{E}_{2}$ to promote macrophage cholesterol efflux needs to be investigated. Increased activity of $\mathrm{CEH}$, but not protein mass, by $\mathrm{E}_{2}$ has been reported (Tomita et al. 1996, Napolitano et al. 2001) and should theoretically lead to increased cholesterol efflux. Because we did not observe an increase in cholesterol efflux, it is unlikely that this occurred in our study to a significant extent. A recent study has shown that when $\mathrm{E}_{2}$ is incorporated into HDL-C particles, the efflux capability of HDL-C is enhanced in THP-1 cells (Badeau et al. 2009). This effect was both ER and SR-B1 dependent (Badeau et al. 2009). $\mathrm{E}_{2}-\mathrm{HDL}-\mathrm{C}$ may represent a more efficient mode of cellular delivery than simply the addition of $\mathrm{E}_{2}$ dissolved in ethanol as we have used. Most of $\mathrm{E}_{2}$ in vivo is bound to plasma proteins such as sex hormone-binding globulin or lipoproteins (Vihma et al. 2003). Therefore, the extracellular lipid environment may play an important role with respect to the effect that $E_{2}$ has on macrophage cholesterol efflux. Recently, it has also been suggested that estrogen may regulate cholesterol transport and uptake through the inhibition of the macrophage SR-A by the $\mathrm{E}_{2}$-induced heat shock protein 27 (Rayner et al. 2010). We have not studied this mechanism of action of $\mathrm{E}_{2}$ in our cell experiments.

In our study, the most plausible explanation for the observed reduction in HMDM CE content by $\mathrm{E}_{2}$ in the absence of increased efflux is reduced cholesterol uptake. We chose THP-1 cells to study the effect of $E_{2}$ on cholesterol accumulation because preliminary experiments by our group as well as by others (Cutolo et al. 2001) have shown that THP-1 cells express ERs.
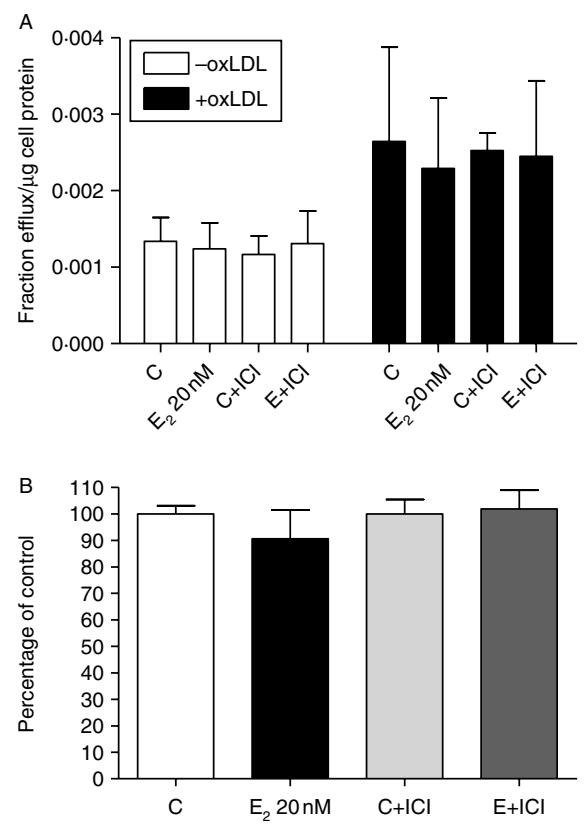

Figure 6 Effect of $E_{2}$ treatment on cholesterol efflux and nascent Dil-LDL uptake in THP-1 macrophages. (A) THP-1 macrophage cells were treated as described in Fig. 2, with or without pretreatment with oxLDL. (B) Cells were treated with control $(C)$, $E_{2} 20 \mathrm{nM}\left(\mathrm{E}_{2}\right), \mathrm{C}+\mathrm{ICl} 182780$, or $\mathrm{E}_{2}+\mathrm{ICl} 182780$ in the presence of $10 \%$ postmenopausal human serum $+5 \mu \mathrm{g} / \mathrm{ml}$ nascent Dil-LDL. Data shown for $A$ and $B$ are representative of four independent experiments, where each treatment was performed in triplicate. 
Cells were exposed to either human serum alone, or human serum supplemented with oxLDL. The percent reduction in $\mathrm{CE}$ content by $\mathrm{E}_{2}$ was greater in cells exposed to human serum without oxLDL than in cells exposed to oxLDL, but the absolute reduction was similar, suggesting that the majority of the effect of $E_{2}$ occurs on macrophages before they are lipid loaded. The magnitude of the $\mathrm{CE}$ reduction by $\mathrm{E}_{2} 20 \mathrm{nM}$ in THP-1 cells exposed to oxLDL was identical to the degree of $\mathrm{CE}$ reduction observed in the HMDMs $(20-30 \%)$ treated with either $\mathrm{E}_{2} 2$ or $20 \mathrm{nM}$. Based on these results, it is possible that a significant portion of the HMDM reduction reported in this study and in previous studies (Sulistiyani \& St Clair 1997, McCrohon et al. 1999) may have occurred prior to exposure to modified lipoproteins.

Observational and randomized intervention studies (Miller et al. 1995, Hulley et al. 1998, Grodstein et al. 2000, 2006, Herrington et al. 2000, Rossouw et al. $2002,2007)$ reveal that the actions of $\mathrm{E}_{2}$ within the vasculature are complex and appear to depend upon numerous factors including age, number of years postmenopause, and the presence of CHD or associated risk factors (Masood et al. 2010). Analysis of the Nurse's Health and WHI studies indicated that women who initiated estrogen replacement therapy closer to menopause had a reduced CHD risk, while women who initiated this therapy farther from menopause had an increased CHD risk (Grodstein et al. 2006, Rossouw et al. 2007). Several hypotheses have been proposed with the predominant 'timing' hypothesis suggesting that an environment without estrogen for a prolonged period of time can lead to an altered vascular state whereby the hormone acts in a different vasotoxic manner compared with a premenopausal/early postmenopausal vascular environment (Xing et al. 2009). Our findings support this hypothesis, specifically in that the effects of $\mathrm{E}_{2}$ on macrophage $\mathrm{CE}$ content are influenced by the extracellular lipoprotein milieu. In a diseased artery, more likely present in the older postmenopausal individual, the presence of oxidized lipoproteins is likely to be significant. $\mathrm{E}_{2}$ may not be as efficacious in a postmenopausal artery that already has a substantial accumulation of cholesterol-laden foam cells, whereas in a healthy artery, $\mathrm{E}_{2}$ may reduce macrophage cholesterol uptake, thereby preventing foam cell formation early on (Salpeter et al. 2009). Two trials, the Kronos Early Estrogen Prevention Study (KEEPS) and the Early versus Late Intervention Trial with Estradiol (ELITE), will test this timing hypothesis (Harman et al. 2005, Taylor \& Manson 2011).

LDL uptake by $\mathrm{E}_{2}$ was reduced, although this effect did not reach statistical significance. This effect may partially be contributing toward the reduction in CE content by $\mathrm{E}_{2}$ as we observed no change in cholesterol efflux, regardless of whether cells were treated with
oxLDL or not. LDL naturally present in human serum is mainly taken up by the LDLR, unlike oxLDL or acetylated LDL (Brown \& Goldstein 1983). Our data indicate that $\mathrm{E}_{2}$ does not affect LDLR protein expression and therefore, the mechanism may involve altered LDL surface binding to the LDLR and subsequent reduction in lipoprotein internalization. This needs to be further investigated. If the effect of $\mathrm{E}_{2}$ on reducing LDL uptake is in part mediated by the LDLR, then this effect would presumably be lost with the oxLDL-induced downregulation of the LDLR from elevated CE accumulation (Linton et al. 1999). Accounting for the remaining reduction in $\mathrm{CE}$ content may include enhanced oxysterol conversion and reductions in de novo cholesterol synthesis.

The reduction in macrophage $\mathrm{CE}$ content by $\mathrm{E}_{2}$ was found to be ER dependent as evidenced by ICI 182780 treatment. This finding is not in agreement with McCrohon et al. (1999), who found that ICI treatment did not prevent the reduction in female HMDM CE accumulation by $\mathrm{E}_{2}$. We used THP-1 cells to test the effect of ICI, and therefore it is possible that HMDMs may respond differently. Interestingly, we observed a significant increase in TC and CE content with ICI in cells that were treated with oxLDL. The mechanism for this effect is unknown. Several studies suggest that ICI may act as an agonist for GPR30, a non-classical estrogen receptor, highlighting the complexities of the estrogen signaling network (Thomas et al. 2005, Filardo et al. 2007). It is unclear whether GPR30 activation may influence macrophage cholesterol metabolism. Alternatively, complete antagonism of the ER in the presence of oxLDL may slightly exacerbate cholesterol accumulation. Since THP-1 cells were cultured in postmenopausal serum, it is possible that the low levels of $\mathrm{E}_{2}$ present in the serum of the non ICI-treated control group may have resulted in enough ER activation to reduce cholesterol accumulation.

In summary, we show that $\mathrm{E}_{2}$, but not testosterone, reduces CE content in HMDM obtained from 50- to 70-year-old donors. The reduction in macrophage CE content by $\mathrm{E}_{2}$ was more pronounced in cells that were not exposed to oxLDL, indicating that oxLDL may mitigate the estrogen response. Clinically, the protective effects of $E_{2}$ replacement in early postmenopausal women without CHD may in part be due to the inhibition of arterial macrophage cholesterol uptake, an effect that is not as potent in the presence of oxLDL such as in advanced atherosclerotic lesions.

\section{Declaration of interest}

The authors declare that there is no conflict of interest that could be perceived as prejudicing the impartiality of the research reported. 


\section{Funding}

This work was supported by the United States Department of Agriculture contract no. 1950-51000-072. Any opinions, findings, conclusions, or recommendations expressed in this publication are those of the authors, and do not necessarily reflect the view of the USDA. M P C was supported by the Unilever Health Science Scholarship and by the NIH training grantT32 HL69772-01A1.

\section{Acknowledgements}

The authors would like to thank Katalin V Horvath for measuring the lipid values of volunteers.

\section{References}

Badeau RM, Metso J, Wahala K, Tikkanen MJ \& Jauhiainen M 2009 Human macrophage cholesterol efflux potential is enhanced by HDL-associated 17beta-estradiol fatty acyl esters. Journal of Steroid Biochemistry and Molecular Biology 116 44-49. (doi:10.1016/j.jsbmb. 2009.04.008)

Berrougui H, Isabelle M, Cloutier M, Grenier G \& Khalil A 2007 Age-related impairment of HDL-mediated cholesterol efflux. Journal of Lipid Research 48 328-336. (doi:10.1194/jlr.M600167JLR200)

Brown MS \& Goldstein JL 1983 Lipoprotein metabolism in the macrophage: implications for cholesterol deposition in atherosclerosis. Annual Review of Biochemistry 52 223-261. (doi:10.1146/ annurev.bi.52.070183.001255)

Buhman KK, Chen HC \& Farese RV Jr 2001 The enzymes of neutral lipid synthesis. Journal of Biological Chemistry 276 40369-40372. (doi:10.1074/jbc.R100050200)

Cathcart MK, McNally AK \& Chisolm GM 1991 Lipoxygenasemediated transformation of human low density lipoprotein to an oxidized and cytotoxic complex. Journal of Lipid Research 32 63-70.

Chen W, Silver DL, Smith JD \& Tall AR 2000 Scavenger receptor-BI inhibits ATP-binding cassette transporter 1 mediated cholesterol efflux in macrophages. Journal of Biological Chemistry $27530794-$ 30800. (doi:10.1074/jbc.M004552200)

Cullen P, Cignarella A, Brennhausen B, Mohr S, Assmann G \& von Eckardstein A 1998 Phenotype-dependent differences in apolipoprotein E metabolism and in cholesterol homeostasis in human monocyte-derived macrophages. Journal of Clinical Investigation 101 1670-1677. (doi:10.1172/JCI119887)

Cutolo M, Villaggio B, Bisso A, Sulli A, Coviello D \& Dayer JM 2001 Presence of estrogen receptors in human myeloid monocytic cells (THP-1 cell line). European Cytokine Network 12 368-372.

Filardo E, Quinn J, Pang Y, Graeber C, Shaw S, Dong J \& Thomas P 2007 Activation of the novel estrogen receptor $\mathrm{G}$ protein-coupled receptor 30 (GPR30) at the plasma membrane. Endocrinology 148 3236-3245. (doi:10.1210/en.2006-1605)

Grodstein F, Manson JE, Colditz GA, Willett WC, Speizer FE \& Stampfer MJ 2000 A prospective, observational study of postmenopausal hormone therapy and primary prevention of cardiovascular disease. Annals of Internal Medicine 133 933-941.

Grodstein F, Manson JE \& Stampfer MJ 2006 Hormone therapy and coronary heart disease: the role of time since menopause and age at hormone initiation. Journal of Women's Health 15 35-44. (doi:10. 1089/jwh.2006.15.35)

Harman SM, Brinton EA, Cedars M, Lobo R, Manson JE, Merriam GR, Miller VM, Naftolin F \& Santoro N 2005 KEEPS: the Kronos Early Estrogen Prevention Study. Climacteric : the Journal of the International Menopause Society 8 3-12. (doi:10.1080/13697130500042417)
Havel RJ, Eder HA \& Bragdon JH 1955 The distribution and chemical composition of ultracentrifugally separated lipoproteins in human serum. Journal of Clinical Investigation 34 1345-1353. (doi:10.1172/ JCI103182)

Herrington DM, Reboussin DM, Brosnihan KB, Sharp PC, Shumaker SA, Snyder TE, Furberg CD, Kowalchuk GJ, Stuckey TD, Rogers WJ et al. 2000 Effects of estrogen replacement on the progression of coronary-artery atherosclerosis. New England Journal of Medicine 343 522-529. (doi:10.1056/NEJM200008243430801)

Hulley S, Grady D, Bush T, Furberg C, Herrington D, Riggs B \& Vittinghoff E 1998 Randomized trial of estrogen plus progestin for secondary prevention of coronary heart disease in postmenopausal women. Heart and Estrogen/progestin Replacement Study (HERS) Research Group. Journal of the American Medical Association 280 605-613. (doi:10.1001/jama.280.7.605)

Kunjathoor VV, Febbraio M, Podrez EA, Moore KJ, Andersson L, Koehn S, Rhee JS, Silverstein R, Hoff HF \& Freeman MW 2002 Scavenger receptors class A-I/II and CD36 are the principal receptors responsible for the uptake of modified low density lipoprotein leading to lipid loading in macrophages. Journal of Biological Chemistry 277 49982-49988. (doi:10.1074/jbc. M209649200)

Langer C, Gansz B, Goepfert C, Engel T, Uehara Y, von Dehn G, Jansen H, Assmann G \& von Eckardstein A 2002 Testosterone up-regulates scavenger receptor BI and stimulates cholesterol efflux from macrophages. Biochemical and Biophysical Research Communications 296 1051-1057. (doi:10.1016/S0006-291X(02)02038-7)

Linton MF, Babaev VR, Gleaves LA \& Fazio S 1999 A direct role for the macrophage low density lipoprotein receptor in atherosclerotic lesion formation. Journal of Biological Chemistry 274 19204-19210. (doi:10.1074/jbc.274.27.19204)

Lloyd-Jones D, Adams RJ, Brown TM, Carnethon M, Dai S, De Simone G, Ferguson TB, Ford E, Furie K, Gillespie C et al. 2010 Executive summary: heart disease and stroke statistics-2010 update: a report from the American Heart Association. Circulation 121 948-954. (doi:10.1161/CIRCULATIONAHA.109. 192666)

Masood DE, Roach EC, Beauregard KG \& Khalil RA 2010 Impact of sex hormone metabolism on the vascular effects of menopausal hormone therapy in cardiovascular disease. Current Drug Metabolism 11 693-714. (doi:10.2174/138920010794233477)

McCrohon JA, Nakhla S, Jessup W, Stanley KK \& Celermajer DS 1999 Estrogen and progesterone reduce lipid accumulation in human monocyte-derived macrophages: a sex-specific effect. Circulation 100 2319-2325. (doi:10.1161/01.CIR.100.23.2319)

McCrohon JA, Death AK, Nakhla S, Jessup W, Handelsman DJ, Stanley KK \& Celermajer DS 2000 Androgen receptor expression is greater in macrophages from male than from female donors. A sex difference with implications for atherogenesis. Circulation 101 224-226. (doi:10.1161/01.CIR.101.3.224)

Miller VT, La Rosa J, Barnabei V, Kessler C, Levin G, Smith-Roth A, Griffin M, Stoy DB, Bush T, Zacur H et al., The Writing Group for the PEPI Trial 1995 Effects of estrogen or estrogen/progestin regimens on heart disease risk factors in postmenopausal women. The Postmenopausal Estrogen/Progestin Interventions (PEPI) Trial. Journal of the American Medical Association 273 199-208.

Napolitano M, Blotta I, Montali A \& Bravo E 2001 17beta-estradiol enhances the flux of cholesterol through the cholesteryl ester cycle in human macrophages. Bioscience Reports 21 637-652. (doi:10. 1023/A:1014721026280)

Ng MK, Quinn CM, McCrohon JA, Nakhla S, Jessup W, Handelsman DJ, Celermajer DS \& Death AK 2003 Androgens up-regulate atherosclerosis-related genes in macrophages from males but not females: molecular insights into gender differences in atherosclerosis. Journal of the American College of Cardiology 42 1306-1313. (doi:10.1016/j.jacc.2003.07.002)

Out R, Hoekstra M, Habets K, Meurs I, de Waard V, Hildebrand RB, Wang Y, Chimini G, Kuiper J, Van Berkel TJ et al. 2008 Combined 
deletion of macrophage ABCA1 and ABCG1 leads to massive lipid accumulation in tissue macrophages and distinct atherosclerosis at relatively low plasma cholesterol levels. Arteriosclerosis, Thrombosis, and Vascular Biology 28 258-264. (doi:10.1161/ATVBAHA.107. 156935)

Rayner K, Chen YX, Siebert T \& O’Brien ER 2010 Heat shock protein 27: clue to understanding estrogen-mediated atheroprotection? Trends in Cardiovascular Medicine 20 54-58. (doi:10.1016/j.tcm.2010.03.008)

Rossouw JE, Anderson GL, Prentice RL, LaCroix AZ, Kooperberg C, Stefanick ML, Jackson RD, Beresford SA, Howard BV, Johnson KC et al. 2002 Risks and benefits of estrogen plus progestin in healthy postmenopausal women: principal results from the Women's Health Initiative randomized controlled trial. Journal of the American Medical Association 288 321-333. (doi:10.1001/jama.288.3.321)

Rossouw JE, Prentice RL, Manson JE, Wu L, Barad D, Barnabei VM, Ko M, LaCroix AZ, Margolis KL \& Stefanick ML 2007 Postmenopausal hormone therapy and risk of cardiovascular disease by age and years since menopause. Journal of the American Medical Association $\mathbf{2 9 7}$ 1465-1477. (doi:10.1001/jama.297.13.1465)

Salpeter SR, Cheng J, Thabane L, Buckley NS \& Salpeter EE 2009 Bayesian meta-analysis of hormone therapy and mortality in younger postmenopausal women. American Journal of Medicine 122 1016.e1-1022.e1. (doi:10.1016/j.amjmed.2009.05.021)

Sulistiyani \& St Clair RW 1997 Effect of 17 beta-estradiol on metabolism of acetylated low-density lipoprotein by THP-1 macrophages in culture. Arteriosclerosis, Thrombosis, and Vascular Biology 17 1691-1700. (doi:10.1161/01.ATV.17.9.1691)

Taylor HS \& Manson JE 2011 Update in hormone therapy use in menopause. Journal of Clinical Endocrinology and Metabolism 96 255-264. (doi:10.1210/jc.2010-0536)

Thomas P, Pang Y, Filardo EJ \& Dong J 2005 Identity of an estrogen membrane receptor coupled to a $\mathrm{G}$ protein in human breast cancer cells. Endocrinology 146 624-632. (doi:10.1210/en.2004-1064)

Tomita T, Sawamura F, Uetsuka R, Chiba T, Miura S, Ikeda M \& Tomita I 1996 Inhibition of cholesterylester accumulation by 17 beta-estradiol in macrophages through activation of neutral cholesterol esterase. Biochimica et Biophysica Acta 1300 210-218.
Vieira OV, Laranjinha JA, Madeira VM \& Almeida LM 1996 Rapid isolation of low density lipoproteins in a concentrated fraction free from water-soluble plasma antioxidants. Journal of Lipid Research 37 2715-2721.

Vihma V, Tiitinen A, Ylikorkala O \& Tikkanen MJ 2003 Quantitative determination of estradiol fatty acid esters in lipoprotein fractions in human blood. Journal of Clinical Endocrinology and Metabolism 88 2552-2555. (doi:10.1210/jc.2002-021898)

Wang X, Collins HL, Ranalletta M, Fuki IV, Billheimer JT, Rothblat GH, Tall AR \& Rader DJ 2007 Macrophage ABCA1 and ABCG1, but not SR-BI, promote macrophage reverse cholesterol transport in vivo. Journal of Clinical Investigation 117 2216-2224. (doi:10.1172/ JCI32057)

Weidtmann A, Scheithe R, Hrboticky N, Pietsch A, Lorenz R \& Siess W 1995 Mildly oxidized LDL induces platelet aggregation through activation of phospholipase A2. Arteriosclerosis, Thrombosis, and Vascular Biology 15 1131-1138. (doi:10.1161/01.ATV.15.8. 1131)

Xing D, Nozell S, Chen YF, Hage F \& Oparil S 2009 Estrogen and mechanisms of vascular protection. Arteriosclerosis, Thrombosis, and Vascular Biology 29 289-295. (doi:10.1161/ATVBAHA.108. 182279)

Yancey PG, Bortnick AE, Kellner-Weibel G, de la Llera-Moya M, Phillips MC \& Rothblat GH 2003 Importance of different pathways of cellular cholesterol efflux. Arteriosclerosis, Thrombosis, and Vascular Biology 23 712-719. (doi:10.1161/01.ATV.0000057572. 97137.DD)

Yla-Herttuala S, Palinski W, Rosenfeld ME, Parthasarathy S, Carew TE, Butler S, Witztum JL \& Steinberg D 1989 Evidence for the presence of oxidatively modified low density lipoprotein in atherosclerotic lesions of rabbit and man. Journal of Clinical Investigation $\mathbf{8 4}$ 1086-1095. (doi:10.1172/JCI114271)

Received in final form 25 May 2011

Accepted 6 June 2011

Made available online as an Accepted Preprint 6 June 2011 